\title{
Influence of Dehydration in the Physical-Chemical Quality of Commercial Sunflower Almonds
}

\author{
Sâmela Leal Barros(Coresponding Author) \\ Federal University of Campina Grande \\ Campina Grande, Paraíba, Brazil \\ E-mail: samelaleal7@gmail.com \\ Newton Carlos Santos, Amanda Priscila da Silva Nascimento, Mylena Olga Pessoa \\ Melo, Victor Herbert de Alcântara Ribeiro, Vírginia Mirtes de Alcântara Silva \\ Federal University of Campina Grande \\ Campina Grande, Paraíba, Brazil
}

Received: July 22, 2019

Accepted: August 7, 2019 Published: August 8, 2019

doi:10.5296/jas.v7i3.15121

URL: https://doi.org/10.5296/jas.v7i3.15121

\begin{abstract}
Sunflower almonds are widely marketed and have numerous technological applications. Through the drying process occurs the reduction of the water content of the product, a factor that contributes to increase its useful life. However, nutritional losses and physical damage can also occur. In this context, the objective of this study was to evaluate the effect of different temperatures applied in the drying process on the physical-chemical characteristics of commercial sunflower almonds. Convective drying was performed using temperatures of 40, 50, 60 and $80{ }^{\circ} \mathrm{C}$. Afterwards, the samples before and after the drying process were analyzed with respect to the following parameters: moisture, water activity, ash, lipids, proteins, carbohydrates and energetic value to observe the influence of different drying temperatures on these attributes. It was verified that the increase of the temperature of the drying air causes an increase in the ash content, total solids, lipids, carbohydrates and energetic value. However, the reduction of moisture content, water activity and proteins was observed. There was no significant difference between the samples in relation to $\mathrm{pH}$.
\end{abstract}

Keywords: drying, Helianthus annuus L, sunflower endosperm, temperature 


\section{Introduction}

The sunflower (Helianthus annuus L.) is a plant native to North America and belongs to the Asteraceae family. It is resistant to adverse climatic conditions and is composed of mesocarp, pericarp (fruit wall) and endosperm (almonds and seeds). (Carvalho et al., 2018). In addition, it can be used in human and animal feeding (Carvalho et al., 2018). In addition to being considered as a major oilseed crop and source of vegetable oils, and to date, traditional sunflower varieties are the main commercially grown varieties, but sunflower varieties with high oleic capacity are of economic importance (Muder et al., 2017).

It stands out for having great economic importance, as it is widely used in the production of edible oil and biodiesel. The internal consumption of sunflower seeds has grown exponentially, due to its high nutritional value, standing out from the other oilseeds because it has a high content of protein, potassium, magnesium and polyunsaturated fatty acids (approximately 31.0\%), (13.1\%), cottonseed (18.1\%), flaxseed (22.4\%), soybean oil (3.5\%), peanut (25.5\%), and safflower seeds (28.2\%) (S` krbic and FIlipčev, 2008; Amorim et al., 2017; Scharlack, 2017).

The quality of the sunflower seeds is influenced by the inherited genetic characteristics of their lineages, germination and vigor, but also by post-harvest processing and storage conditions (Gvozdenac et al., 2018). Its harvesting is carried out when the product has reached the appropriate physiological maturity, where the best yields, higher dry matter content and high moisture content are verified. However, for adequate processing and storage to occur, it is essential to reduce the moisture content through the application of unitary operations such as convective drying, which is the process most used in agricultural products and which provides the reduction of activity chemical and biological properties, guaranteeing the quality and stability of the final product (Smaniotto et al., 2017).

Drying is one of the most important stages of post-harvesting, involving both the transfer of heat and mass through the application of high temperatures that cause evaporation of water in the product. Multiple physical and biochemical processes are also associated with the drying process, such as shrinkage, cracking and loss of thermosensitive compounds. The mathematical modeling applied to the drying process aims to predict the behavior of the raw material in relation to the loss of moisture over time, to size equipment and perform the optimization of the process, providing a reduction in the drying time and consequently the reduction of costs and greater nutritional preservation of the product (Defraeye and Radu, 2018; Keneni et al., 2019).

Considering the importance of the study of the drying process in agricultural products, the present work had the objective of evaluating the effect of different drying temperatures on the physical-chemical characteristics of commercial sunflower almonds.

\section{Material and Methods}

The study was conducted in the Food Engineering Laboratory (LEA), located in the Natural Resources and Technology Center (CTRN) of the Federal University of Campina Grande, Campina Grande - Paraíba. 


\section{Macrothink Institute ${ }^{\mathrm{TM}}$}

The sunflower's (Helianthus annuus L.) almonds were purchased at the fair of the city of Campina Grande - PB and taken to the laboratory (LEA), where they were submitted to the drying process in an oven with air circulation at a temperature of 40,50,60,70 and $80 \varnothing \mathrm{C}$, in which the samples were evenly distributed in trays (Figure 1), forming a thin layer. After dehydration, the samples were crushed in a knife mill where they were left with flour textures with irregular granulometry. Then packed and stored in laminated and vacuum sealed packages.

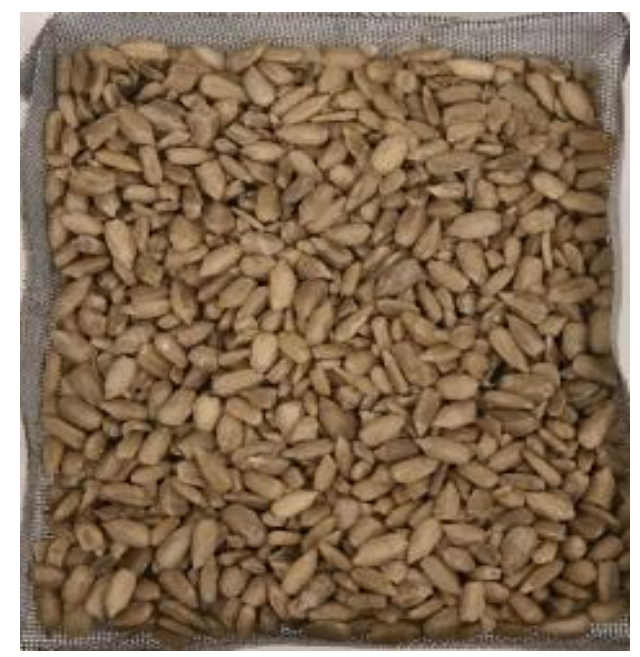

Figure 1. Commercial sunflower almonds

\subsection{Physical-Chemical Characterization}

The commercial sunflower kernels before and after the drying process were characterized according to the following physicochemical parameters: moisture, total solids, $\mathrm{pH}$, ash and protein followed the methodologies described by the Instituto Adolf Luttz (Brazil, 2008). Water activity (Aw) was determined using the Decagon ${ }^{\circledR}$ Aqualab CX-2T device at $25^{\circ} \mathrm{C}$; The total carbohydrate content was calculated by difference to obtain $100 \%$ of the total composition (FAO, 2003). The lipid content was determined according to the methodology described by Bligh and Dyer (1959). The energy value was calculated according to the methodology proposed by Rocha Júnior et al. (2003).

\subsection{Statistical Analysis}

The data obtained in relation to the physico-chemical characterization of the dehydrated samples were statistically evaluated by means of a completely randomized design and the means compared by the Tukey test at $5 \%$ probability, with the aid of the statistical program ASSISTAT version 7.7 beta (Silva and Azevedo, 2016).

\section{Results and Discussion}

Table 1 shows the results obtained for the physico-chemical characterizations performed on commercial sunflower kernels before the drying process. 


\section{Macrothink}

Table 1. Physical-chemical characterization of commercial sunflower kernels before the drying process

\begin{tabular}{ll}
\hline Parameters & Commercial almonds \\
\hline Moisture (\%) & $14.60 \pm 0.05$ \\
Total solids (\%) & $85.40 \pm 0.05$ \\
Water activity (Aw) & $0.534 \pm 0.01$ \\
$\mathrm{pH}$ & $6.81 \pm 0.02$ \\
Titratable Acidity (\%) & $1.7 \pm 0.1$ \\
Ashes (\%) & $3.04 \pm 0.04$ \\
Lipids (\%) & $8.16 \pm 0.47$ \\
Proteins (\%) & $17.09 \pm 0.64$ \\
Carbohydrates (\%) & $57.11 \pm 0.28$ \\
Energetic value (Kacal/100g) & $370.24 \pm 0.32$ \\
\hline
\end{tabular}

Commercial almonds before the drying process had a moisture content of $14.60 \%$ and total solids content inversely proportional to their moisture content. Silva et al. (2019) determined in lentil seeds moisture content (10.5\%) and total solids of (89.5\%). Fellow (2006) classified as intermediate moisture products those with aw between 0.6 and 0.85 and products with low humidity are those with aw values up to 0.6. We can classify sunflower almonds as intermediate moisture products (0.534). Brito et al. (2015) when analyzing for 90 days urucun seeds obtained water activity ranging from 0.630 to 0.673 .

Before the drying process, they obtained $\mathrm{pH}$ close to neutrality. Close values were also obtained by Silva et al. (2017) for chickpeas (6.37 - 6.57). The value of titratable acidity (1.7\%) was higher than the values found by Silva et al. (2017) for whole sunflower seeds with bark $(0.774-0.830 \%)$.

The ash content was higher than those obtained by Silva et al. (2017) for gyrosol seeds with bark (1.75-2.06\%), evidencing that the almonds have a significant amount of this parameter. However, it presents lower lipid content when compared to studies by Santos et al. (2017) for favela seeds (35.20\%).

High values were also obtained for protein content (17.09\%) and for carbohydrate content (57.11\%). Feitosa et al. (2017) quantified $4.75 \%$ protein in jackfruit almonds. These high levels show that the almonds have a considerably elevated energy value $(370.24 \mathrm{kcal} / 100 \mathrm{~g})$.

Table 2 shows the physical-chemical characterization and energetic value of commercial sunflower almonds after the drying process at temperatures of $40,50,60,70$ and $80{ }^{\circ} \mathrm{C}$. 
Table 2. Physical-chemical characterization of dehydrated sunflower almonds

\begin{tabular}{llllll}
\hline \multirow{2}{*}{ Parameters } & \multicolumn{5}{l}{ Convective drying $\left({ }^{\circ} \mathrm{C}\right)$} \\
\cline { 2 - 6 } & 40 & 50 & 60 & 70 & 80 \\
\hline Moisture (\%) & $10.04^{\mathrm{a}}$ & $9.07^{\mathrm{b}}$ & $7.58^{\mathrm{c}}$ & $5.78^{\mathrm{d}}$ & $2.91^{\mathrm{e}}$ \\
Total solids (\%) & $89.96^{\mathrm{e}}$ & $90.93^{\mathrm{d}}$ & $92.42^{\mathrm{c}}$ & $94.22^{\mathrm{b}}$ & $97.09^{\mathrm{a}}$ \\
Water activity (Aw) & $0.416^{\mathrm{a}}$ & $0.406^{\mathrm{b}}$ & $0.365^{\mathrm{c}}$ & $0.360^{\mathrm{cd}}$ & $0.356^{\mathrm{d}}$ \\
$\mathrm{pH}$ & $6.82^{\mathrm{a}}$ & $6.83^{\mathrm{a}}$ & $6.85^{\mathrm{a}}$ & $6.83^{\mathrm{a}}$ & $6.82^{\mathrm{a}}$ \\
Titratable Acidity (\%) & $1.44^{\mathrm{a}}$ & $1.33^{\mathrm{a}}$ & $1.30^{\mathrm{a}}$ & $1.03^{\mathrm{b}}$ & $1.46^{\mathrm{a}}$ \\
Ashes (\%) & $3.15^{\mathrm{e}}$ & $3.64^{\mathrm{d}}$ & $3.96^{\mathrm{c}}$ & $4.26^{\mathrm{b}}$ & $4.83^{\mathrm{a}}$ \\
Lipids (\%) & $7.01^{\mathrm{b}}$ & $7.69^{\mathrm{ab}}$ & $7.84^{\mathrm{ab}}$ & $8.15^{\mathrm{a}}$ & $8.22^{\mathrm{a}}$ \\
Proteins (\%) & $19.14^{\mathrm{b}}$ & $20.28^{\mathrm{a}}$ & $16.04^{\mathrm{c}}$ & $13.55^{\mathrm{d}}$ & $12.1^{\mathrm{e}}$ \\
Carbohydrates (\%) & $60.3^{\mathrm{d}}$ & $59.32^{\mathrm{e}}$ & $64.58^{\mathrm{c}}$ & $68.26^{\mathrm{b}}$ & $71.94^{\mathrm{a}}$ \\
Energetic value & $380.85^{\mathrm{e}}$ & $387.61^{\mathrm{d}}$ & $393.04^{\mathrm{c}}$ & $400.59^{\mathrm{b}}$ & $410.14^{\mathrm{a}}$ \\
(Kacal/100g) & & & & & \\
\hline
\end{tabular}

Note: Letter superscripts equal in the same line do not present significant difference at the $5 \%$ probability level.

The final moisture content obtained for all temperatures were relatively low, differing statistically from each other. There was a reduction of this parameter of $7.13 \%$ between the almonds submitted to 40 and $80{ }^{\circ} \mathrm{C}$. According to Santos et al. (2019) the moisture content is inversely proportional to the applied temperature, ie, the higher the drying temperature the lower the moisture content of the product. It was also verified that the amount of total solids was higher when using higher temperatures $\left(80{ }^{\circ} \mathrm{C}\right)$, presenting $97.06 \%$, this increase of the total solids content is justified by the reduction of the water content of the almonds. As well as the moisture content the total solids content also presented statistical differences at the 5\% probability level.

The values obtained for the water activity corroborate with the data obtained for the moisture content, since they also reduced with the increase of the temperature of the drying air, varying from 0.416 to 0.356 when the temperature ranged from 40 to $80{ }^{\circ} \mathrm{C}$. Statistically, only the almonds submitted to a temperature of $70{ }^{\circ} \mathrm{C}$ did not present a significant difference between those submitted to 60 and $80{ }^{\circ} \mathrm{C}$, but presented differences of those submitted to 40 and $50{ }^{\circ} \mathrm{C}$. According to Silva et al. (2019) water activity is one of the main properties when considering the processing, storage and storage stages of agricultural products.

The $\mathrm{pH}$ values obtained at all drying temperatures were close to neutrality $(\mathrm{pH}=7.00)$, ranging from 6.82 to 6.85 , however, they did not present significant statistical differences. Bouvie et al. (2016) obtained $\mathrm{pH}$ of 5.23 and 6.23 for mesocarp and exocarp of Brazil nut tree (Bertholletia excelsa), respectively. When analyzing the titrable total acidity, only the almonds submitted to temperature of $70{ }^{\circ} \mathrm{C}$ presented differences when compared to the others according to the Tukey test at $5 \%$ of probability. This same parameter had values lower than $1.5 \%$. According to Aroucha et al. (2010) the acidity has great utility in the food industry as a preservative, index for quality evaluation, sensorial indicator among other functions.

The ash quantification showed statistical differences between all the applied temperatures, 
with a gain with the increase of temperature, in relation to the almonds before the drying process (Table 1) there was a gain of up to $1.79 \%$ when the temperature ranged from 40 to $80{ }^{\circ} \mathrm{C}$. Values close to the present study were quantified Kato et al. (2016), which obtained $5.44 \%$ for brazil nut cake after the cold pressing process.

In relation to the lipid content, the almonds obtained similar behavior to the ash content, that is, there was also a gain with increase of the drying temperature, being the highest content obtained for the temperature of $80{ }^{\circ} \mathrm{C}(8.22 \%)$ and the lowest temperature for $40{ }^{\circ} \mathrm{C}(7.01 \%)$. Statistically, the seeds submitted at 50 and $60{ }^{\circ} \mathrm{C}$ did not show any differences between them, as well as those submitted at 70 and $80{ }^{\circ} \mathrm{C}$. Lower values were observed by Lemos et al. (2015) when analyzing noni seeds (6.34\%).

There was a gain of $1.14 \%$ in the protein content between the temperatures of 40 and $50{ }^{\circ} \mathrm{C}$, however, from the temperature of $60^{\circ} \mathrm{C}$, it was noticed degradation of this content being the seeds submitted to $80{ }^{\circ} \mathrm{C}$ with lower content protein (12.1\%). All applied temperatures presented statistical difference. Ortolan et al. (2016) obtained $21.17 \%$ of proteins for baru seeds dehydrated at $140{ }^{\circ} \mathrm{C}$, being close to that obtained for almonds submitted to $50{ }^{\circ} \mathrm{C}$ in the present study. Malacrida et al. (2007) obtained $20.1 \%$ protein for dried yellow melon seeds at $40{ }^{\circ} \mathrm{C}$.

The results obtained in this work for the total carbohydrates content, presented a variation of 60.3 to $71.94 \%$, being these respectively for the almonds submitted to the temperatures of 40 and $80{ }^{\circ} \mathrm{C}$, evidencing, that the sunflower almonds are rich in fibers. When compared to each other, they presented statistical difference at the $5 \%$ probability level. Lower carbohydrate values were obtained by Amaral et al. (2019) when they obtained flours of the fruit bocaiuva in the temperature between 40 and $50{ }^{\circ} \mathrm{C}(46,36 \%)$.

This high carbohydrate content contributes considerably to its high energy value, and can contribute significantly to raise the food standard of the population. As the drying temperature increased, an increase in the energetic value of the almonds was observed, ranging from 380.85 to $410.14 \mathrm{Kcal} / 100 \mathrm{~g}$, presenting a statistical difference between the applied temperatures.

\section{Conclusion}

Through the evaluation of the physicochemical parameters in the different treatments applied, it was verified that the increase of the temperature provided the reduction of moisture content, water activity and proteins. In contrast, there was an increase in ash content, total solids, lipids, carbohydrates and energetic value. No statistically significant difference was observed between the samples with respect to $\mathrm{pH}$, however, for the acid parameter only the sample submitted to a temperature of $70{ }^{\circ} \mathrm{C}$ differed from the others. And the almonds submitted to $50{ }^{\circ} \mathrm{C}$ obtained the highest protein content and lipid content, so it is considered to be the ideal temperature for the drying process of sunflower almonds.

\section{Acknowledgement}

National Council for Scientific and Technological Development - CNPQ 


\section{References}

Amaral, L. A., Loubet Filho, P. S., Cavalheiro, L. F., Galvani, F., \& Santos, E. F. (2019). Comparação das propriedades químicas e do perfil lipídico das farinhas de bocaiuva (Acrocomia spp.) despolpada de forma manual e mecânica. Revista de Agricultura Neotropical, 6(2), 59-63. https://doi.org/10.32404/rean.v6i2.2737

Amorim, M. Q., Nascimento, E. M. S., Oliveira, J. L. P., Lopes, J. E. L., \& Chioderoli, C. A. L. (2017). Qualidade fisiológica de sementes de girassol em função do teor de água e do sistema de trilha. Global Science and Technology, 10(03), 95-105.

Aroucha, E. M. M., Gois, V. A., Leite, R. H. L., Santos, M. C. A., \& Souza, M. S. (2010). Acidez em frutas e hortaliças. Revista Verde de Agroecologia e Desenvolvimento Sustentável, 5(2), 01-04.

Bligh, E. G., \& Dyer, W. J. (1959). A rapid method of total lipid extraction and purification. Canadian Journal Biochemistry Physiology, 37, 911-917.

https://doi.org/10.1139/y59-099

Bouvie, L., Borella, D. R., Porto, P. A. O., Silva, A. C., \& Leonel, S. (2016). Caracterização físico-química dos frutos de castanheira do Brasil. Revista Nativa, 4(2), 107-111.

https://dx.doi.org/10.14583/2318-7670.v04n02a10

Brasil, Instituto Adolfo Lutz. (2008). Métodos físico-químicos para análise de alimentos (4th ed., Volume 1, p.1020). São Paulo: Instituto Adolfo Lutz.

Brito, J. G., Queiroz, A. J. M., Figueirêdo, R. M. F., \& Oliveira, A. S. (2015). Storage of waste grains of annatto under controlled atmosphere. Revista Brasileira de Engenharia Agrícola e Ambiental, 19(12), 1185-1191.

https://dx.doi.org/10.1590/1807-1929/agriambi.v19n12p1185-1191

Carvalho, J. M. G., Bueno, S. G. S., Oliveira, D. E. C., \& Resende, O. (2018). Modelagem matemática e propriedades termodinâmicas da secagem do grão de girassol. Global Science and Technology, 11(02), 136-149.

Defraeye, T., \& Radu, A. (2018). Insights in convective drying of fruit by coupled modeling of fruit drying, deformation, quality evolution and convective exchange with the airflow. Applied Thermal Engineering, 129, 1026-1038.

DOI:10.1016/j.applthermaleng.2017.10.082

FAO. Food and Agriculture Organization of the United Nations. Food Energy: Methods of Analysis and Conversion Factors. Report of a Technical Workshop; Food and Nutrition Paper Volume 77; FAO: Rome, Italy, 2003.

Feitosa, R. M., Queiroz, A. J. M., Figuêredo, R. M. F., \& Melo, J. C. S. (2017). Physicochemical and sensory evaluation of jackfruit cooked almonds. Revista de Ciências Agroambientais, 15(1), 83-89.

Fellows, P. J. (2006). Tecnologia do Processamento de Alimentos - Princípios e práticas. 
Artmed.

Gvodenac, S. M., Prvulovic, D. M., Radovanovic, M. N., Ovuka, J. S., Miklic, V. J., Acanski, J. M., ... Vukajlovic, F. N. (2018). Life history of Plodia interpunctella Hübner on sunflower seeds: Effects of seed qualitative traits and the initial seed damage. Jounal of Stored Products Research, 79, 89-97. https://doi.org/10.1016/j.jspr.2018.08.003

Kato, C. G., Brugnari, T., Correa, V. G., Gomes, R. G., \& Salem, R. D. S. (2016). Physicochemical characterization of Brazilian nut pie (Bertholletia excelsa H.B.K) obtained by pressing for technological achievement. Revist Uningá, 25(2), 07-11.

Keneni, Y. G., Hvoslef-Eide, A. K. (Trine), \& Marchetti, J. M. (2019). Mathematical modelling of the drying kinetics of Jatropha curcas L. seeds. Industrial Crops and Products, 132, 12-20. https://dx.doi.org/10.1016/j.indcrop.2019.02.012

Lemos, D. M., Queiroz, A. J. M., \& Figueirêdo, R. M. F. (2015). Physicochemical characterization of noni seeds. Revista Gestão, Inovação e Tecnologias, 5(3), 2308-2315. https://dx.doi.org/10.7198/S2237-0722201500030008

Malacrida, C. R., Angelo, P. M., Andreo, D., \& Jorge, N. (2007). Composição química e potencial antioxidante de extratos de sementes de melão amarelo em óleo de soja. Revista Ciência Agronômica, 38(4), 372-376.

Muder, S., Argyropoulos, D., \& Muller, J. (2017). Class-based physical properties of air-classifiedsunflower seeds and kernels. Biosytems Engineerring, 164, 124-134. DOI:https://doi.org/10.1016/j.biosystemseng.2017.10.005

Ortolan, A. V., Eing, K. K. C., Santos, M. M. R., Cândido, C. J., Santos, E. F., \& Novello, D. (2016). Baru flour in cupcakes: physico-chemical and sensory characterization among children. Revista o Mundo da Saúde, 40(2), 213-220.

Rocha Júnior, V. R., Valadares Filho, S. C., Borges, A. M., Detmann, E., Magalhães, K. A., Valadares, R. F. D., ... Cecon, P. R. (2003). Estimative of Energy Value of Feed and Validation of Equations Proposed by NRC (2001). Revista Brasileira de Zootecnologia, 32(2), 480-490.

S`krbic, B., \& Filipc`ev, B. (2008). Nutritional and sensory evaluation of wheat breads supplemented with oleic-rich sunflower seed. Food Chemistry, 108(1), 119-129. https://doi.org/10.1016/j.foodchem.2007.10.052

Santos, K. A., Aragão Filho, O. P., Aguiar, C. M., Milinsk, M. C., Sampaio, S. C., Palú, F., \& Silva, E. D. (2017). Chemical composition, antioxidant activity and thermal analysis of oil extracted from favela (Cnidoscolus quercifolius) seeds. Industrial Crops and Products, 97, 368-373. https://doi.org/10.1016/j.indcrop.2016.12.045

Santos, N. C., Barros, S. L., Almeida, R. L. J., Nascimento, A. P. S., \& Almeida, R. D. (2019). Influence of temperature in the centesimal composition of pitomba shell (Talisia esculenta). Revista Higiene Alimentar, 33, 1477-1481. 


\section{I Macrothink}

Scharlack, N. K. Estudo do efeito do tipo e grau de hidratação de solventes alcoólicos na extração simultânea de óleo e de ácidos clorogênicos de torta de sementes de girassol. 126f. 2015. Dissertação (Mestrado em Ciências e Tecnologia dos Alimentos) - Universidade de São Paulo, Pirassununga - SP.

Silva, F. A. S., \& Azevedo, C. A. V. (2016). The Assistat Software Version 7.7 and its use in the analysis of experimental data. African Journal Agricultural Research, 11, 3733-3740. https://doi.org/10.5897/AJAR 2016.11522

Silva, L. P. F. R., Silva, S. N., Silva, R. C., Candido, A. F. M., Dantas, M. C. A. M., \& Gomes, J. P. (2017). Propriedades físico-químicas das sementes de girassol oriundas de diferentes localidades. In: Amistrong Martins da Silva (Org). A agroindústria e os desafios da segurança alimentar: Produção e/ou tecnologia animal e vegetal. Instituto Bioeducação, 2, 805-813.

Silva, P. B., Matos, J. D. P., Pereira, J. C. A., Silva, S. N., \& Gomes, J. P. (2017). Propriedades físicas e químicas de grão-de-bico comercializado no município de Campina Grande, PB. In: Amistrong Martins da Silva (Org). A agroindústria e os desafios da segurança alimentar: Produção e/ou tecnologia animal e vegetal. Instituto Bioeducação, 2, 797- 804.

Silva, S. N., Pereira Filho, M. D., Guedes, M. H. S., Sousa, M. T. L., Gomes, J. P., Santos, N. C., ... Riberio, V. M. A. (2019). Determination of the Physical Properties of Grains of Lens culinaris L. Journal of Scientific and Engineering Research, 6(4), 36-40.

Silva, V. M. A., Ribeiro, V. H. A., Santos, N. C., Barros, S. L., Nascimento, A. P. S., \& Almeida, R. L. J. (2019). Obtenção e caracterização físico-química da farinha de beterraba em diferentes temperaturas. In: Francisco, Paulo Roberto Megna (Org.). Caderno de Pesquisa, Ciência e Inovação, 2(1), 73-81.

Smaniotto, T. A. S., Resende, O., Sousa, K. A., Oliveira, D. E. C., Campos, R. C. (2017). Drying kinetics of sunflower grains. Revista Brasileira de Engenharia Agrícola e Ambiental, 21(3), 203-208.

https://dx.doi.org/10.1590/1807-1929/agriambi.v21n3p203-208

\section{Copyright Disclaimer}

Copyright for this article is retained by the author(s), with first publication rights granted to the journal.

This is an open-access article distributed under the terms and conditions of the Creative Commons Attribution license (http://creativecommons.org/licenses/by/3.0/). 